\title{
Frequency of Epstein Barr Virus in Non-Hodgkin's Lymphoma Determined by Latent Membrane Protein 1 Expression
}

\author{
Jaseela T. K. ${ }^{1}$, Letha V. ${ }^{2}$, Jayalakshmi P. L. ${ }^{3}$, Sankar Sundaram ${ }^{4}$ \\ ${ }^{1}$ Department of Pathology, Government Medical College, Kottayam, Kerala, India. ${ }^{2}$ Department of Pathology, \\ Government Medical College, Kottayam, Kerala, India. ${ }^{3}$ Department of Pathology, Government Medical College, \\ Kottayam, Kerala, India. ${ }^{4}$ Department of Pathology, Government Medical College, Kottayam, Kerala, India.
}

\section{ABSTRACT}

\section{BACKGROUND}

Non-Hodgkin's Lymphoma is a haematological malignancy with various etiological factors and one among them is Epstein Barr Virus. The expression of Epstein-Barr virus in Non-Hodgkin's lymphoma can be identified by immunohistochemistry for detection of Epstein-Barr virus latent membrane protein (LMP-1). In our study, we are trying to clarify the extent of expression LMP-1 in our population. This can be used as a prognostic marker and for therapeutic interventions targeting EBV encoded proteins. We wanted to determine the proportion of LMP1 (EBV marker) expression in Non-Hodgkin's Lymphoma and evaluate the association of LMP1 expression in B cell and T cell type of NHL.

\section{METHODS}

This is a cross sectional analytical study conducted at Department of Pathology, Govt. Medical College, Kottayam, from December 2017 to May 2019. A total of 67 cases were studied. All of them were histopathologically diagnosed Non-Hodgkin's Lymphoma specimens received in the Department of Pathology, Govt. Medical College, Kottayam, during the study period of 18 months. NHL was subtyped into B cell type and T cell type. LMP-1 immunohistochemistry was done on all cases to assess its expression. Then analysis was done using SPSS software and strength of association between LMP 1 positivity and cell type was calculated using Chi square test and Fisher's exact test.

\section{RESULTS}

Mean age of Non-Hodgkin's lymphoma is $57.82+/-7.4$ in this study. Minimum age is 2 years and maximum age is 89 years. The present study had $10.4 \%$ LMP 1 positive cases. Of which there were $6 \%$ moderately stained positive cases, $3 \%$ of weakly stained cases and $1.5 \%$ cases of intensely stained cases. Among NHL $86.6 \%$ cases were B cell lymphoma and $13.4 \%$ cases of T cell lymphoma. And they had a LMP 1 positivity of $10.3 \%$ and $11.1 \%$ respectively. But there was no significant association between LMP 1 positivity and cell type according to our study.

\section{CONCLUSIONS}

The present study was done to determine the proportion of LMP 1 expression in Non-Hodgkin's Lymphoma and to find out whether there is any association between LMP1 expression in B cell and T cell type of NHL. LMP 1 was positive in $10.4 \%$ of NHL and there was no association between LMP 1 positivity in B cell and T cell Lymphoma. This suggest that EBV might play a role in pathogenesis of NHL.

\section{KEY WORDS}

Non-Hodgkin's Lymphoma, Latent Membrane Protein 1, Epstein Barr Virus
Corresponding Author:

Letha $V$.,

Department of Pathology,

Government Medical College,

Kottayam, Kerala, India.

E-mail:drjaseelatk@gmail.com

DOI: $10.14260 /$ jemds $/ 2020 / 312$

Financial or Other Competing Interests: None.

How to Cite This Article:

Jaseela TK, Letha V, Jayalakshmi PL, et al. Frequency of epstein barr virus in non hodgkins lymphoma determined by latent membrane protein 1 expression. J. Evolution Med. Dent. Sci. 2020;9(17): 1431-1434, DOI:

10.14260/jemds/2020/312

Submission 11-01-2020,

Peer Review 12-04-2020,

Acceptance 18-04-2020,

Published 27-04-2020.

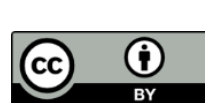




\section{BACKGROUND}

Lymphoma is a haematological malignancy that arises from lymphocytes. They are a heterogeneous group of malignancies and can be classified mainly into Hodgkin lymphoma and Non-Hodgkin's lymphoma. ${ }^{1}$ In the year 2018 according to the International agency for research on cancer incidence of NHL in India is $2.4 \% .^{2}$ And its incidence is increasing. Currently only a few data are available as to what causes Non-Hodgkin's Lymphoma. We know only some of the risk factors of Non-Hodgkin's Lymphoma. Studies related to patterns of cancer in the population has identified certain risk factors which are observed to be more common in people who get Non-Hodgkin's Lymphoma than in those who do not. NHL is more common among people with immunodeficiency and people with increased exposure to certain chemicals, such as fertilizers, pesticides, or solvents are more prone to develop this disease. ${ }^{3}$ In developed countries adequate information is available on epidemiology of Non-Hodgkin's lymphoma. But such studies exploring the epidemiology of NHL is very few in developing countries like India.

EBV is an oncogenic DNA virus and it has been implicated in the pathogenesis of several cancers like nasopharyngeal carcinoma, African form of Burkitt lymphoma, some gastric carcinoma and various other subtypes of lymphoma (Hodgkin's lymphoma, DLBCL, NK/T cell lymphoma). EBV have tropism for B-lymphocytes. Usually EBV causes a transient infection called Infectious mononucleosis. But in some people it causes latent infection. These B Cells with latent infection may transform into continuously proliferating blast cells and later to lymphoma. ${ }^{4}$

EBV approximately infects most of the adult population in the world. It encodes a series of products which interacts with or are similar to many of antiapoptotic molecules, cytokines, and signal transducers. This enhances EBV infection, defective apoptosis and malignant transformation. LMP-1 (Latent Membrane Protein 1) is an integral transmembrane protein encoded by LMP gene of EBV. It is an oncogene and acts as a constitutively active CD 40 receptor, which stimulate B-cell growth. It promotes B-cell survival and proliferation which occurs autonomously (i.e. without T-cells or other signals which causes B-cell proliferation). LMP-1 also have anti-apoptotic activity. It activates $\mathrm{Bcl} 2$ and escapes from apoptosis thus becoming immortal. Therefore LMP-1 expression has been suggested to have oncogenic effect in the development and progression of lymphoma which occurs due to Epstein Barr Virus. There are studies which says that patients with EBV marker positivity has bad prognosis than patients with EBV marker negativity. So it can also be used as a prognostic marker. It is also getting attention as a new target for anti-lymphoma therapy. 5 This study aims to determine the proportion of LMP 1 (EBV marker) expression in Non-Hodgkin's Lymphoma.

\section{METHODS}

This is a cross sectional analytical study conducted from December 2017 to May 2019 in the Department of Pathology,
Govt. Medical College, Kottayam among 67 specimens of cases of histopathologically diagnosed Non-Hodgkin's Lymphoma received in the Department of Pathology, Govt. Medical College, Kottayam during the study period of 18 months.

\section{Sample Size}

Sample size was determined using the formula

$$
\mathrm{N}=\frac{\mathrm{Z} \alpha^{2} \mathrm{pq}}{\mathrm{d}^{2}}
$$

$\mathrm{Z} \alpha=1.96$ at $95 \% \mathrm{CI}$

$\mathrm{p}=$ prevalence $/$ proportion in previous study

$\mathrm{q}=100-\mathrm{p}$

$\mathrm{d}=$ precision/ allowable error

Proportion of NHL cases which showed LMP-1 positivity in a study "LMP1 immunohistochemistry in Non-Hodgkin's lymphoma of Sudanese cases" conducted by Amal Ismail et al is $17.3 \%$

So, $\mathrm{p}=17.3, \quad \mathrm{q}=100-17.3=82.7$

Taking absolute precision as $9 \%$.

Sample size, $\mathrm{N}=\underline{\mathrm{Z} \alpha^{2} \mathrm{pq}}=(1.96)^{2} \times 17.3 \times 82.7=67$

$$
\mathrm{d}^{2} \quad(9 \times 9)^{2}
$$

Calculated sample size is 67.

\section{Inclusion Criteria}

All cases of Non-Hodgkin lymphoma i.e. both nodal and extranodal; confirmed by histopathology and IHC, as B cell and $\mathrm{T}$ cell type.

\section{Exclusion Criteria}

Cases diagnosed as Hodgkin's Lymphoma and those with inconclusive diagnosis and those with a diagnosis given only as Lymphoproliferative disorder

\section{Study Tools}

1. Instruments to take bits of tissues to be studied.

2. Reagents for tissue processing.

3. Instruments for making paraffin blocks and cutting thin sections from it.

4. Glass slides and cover slips for mounting.

5. Microscope

6. Eosin- Haematoxylin stain

7. Ready to use monoclonal mouse LMP 1 antibody and other reagents for immunohistochemical studies.

8. Proforma to record clinicopathological details

\section{Study Procedure}

Clinical and pathological details of each cases were recorded as in the proforma. All specimens were fixed in formalin \& embedded in paraffin. Sections were taken from paraffin 
embedded blocks and stained with H\&E for routine examination. IHC was performed using monoclonal mouse EBV LMP1 antibody (dako) on NHL specimens and was evaluated. Only histopathologically proven cases of NHL which has been subtyped as B cell or T cell NHL was taken for IHC.

Interpretation of positive slides was done with a light microscope. Positive results were considered if there were cytoplasmic and membranous staining. Aberrant nuclear staining was considered negative. Scoring was done on the basis of the percentage of positive tumour cells and the relative immune staining intensity. Number of positive tumour cells were scored as: 0 - none seen in the section; 1 presence of positive cells even rare but not exceeding $25 \%$; 2 $26 \%$ to $50 \%$ positive cells; $3-51 \%$ to $75 \%$; and $4-76 \%$ to $100 \%$. Immune-staining intensity was rated as follows: 0 none; 1 - weak; 2 - moderate and 3- intense.

\section{Statistical Analysis}

The data was entered in Microsoft excel and further statistical analysis was done using SPSS software (version 24). Mean, frequency and proportion for age, sex, site, cell type, histopathological diagnosis, LMP 1 immunohistochemistry and intensity of LMP 1 staining were determined. Association between LMP 1 positivity and Cell type was calculated using Chi- Square Test and Fisher's exact test.

\section{RESULTS}

Cross sectional analytical study of frequency of LMP-1 positivity in 67 cases of Non-Hodgkin's Lymphoma was conducted in the department of Pathology, Government Medical College, Kottayam during the study period of 18 months. The mean age distribution of the present study population was $57.82+-7.4$ years with age ranging from 2 years to 89 years. Majority belong to age group 61-75 years (49\%). Most of them (70.1\%) were male patients. None of the patients were immunocompromised in the present study. $59.7 \%$ of patients had lymphoma involving the lymph node and $40.3 \%$ had extranodal lymphoma. Most common node involved was cervical (55\%) followed by supraclavicular (15\%) and axillary (15\%).

\begin{tabular}{|ccc|}
\hline Age Group & Frequency & Percentage (\%) \\
$0-15$ & 2 & 3 \\
$16-30$ & 4 & 6 \\
$31-45$ & 4 & 6 \\
$46-60$ & 20 & 29.9 \\
$61-75$ & 33 & 49.3 \\
$>75$ & 4 & 6 \\
Total & $\mathbf{6 7}$ & $\mathbf{1 0 0}$ \\
\hline \multicolumn{3}{|c}{ Table 1. Age Distribution of Study Group } \\
\hline
\end{tabular}

\begin{tabular}{|ccc|}
\hline Histopathology & Frequency & (\%) \\
DLBCL & 38 & 56.7 \\
Follicular Lymphoma & 17 & 25.4 \\
Peripheral T cell lymphoma, NOS & 4 & 6 \\
Anaplastic large cell lymphoma & 2 & 3 \\
SLL/CLL & 2 & 3 \\
T cell rich B cell lymphoma & 1 & 1.5 \\
Cutaneous T cell lymphoma & 3 & 4.5 \\
Total & $\mathbf{6 7}$ & $\mathbf{1 0 0}$ \\
\hline Table 2. Distribution of Lymphomas According & \\
to Histopathological Diagnosis & \\
\hline
\end{tabular}

By assessing light microscopic examination of $\mathrm{H} \& \mathrm{E}$ and IHC stained slides $86.6 \%$ of cases were found to be B cell type and $13.6 \%$ of cases were $\mathrm{T}$ cell type. When subtyped based on the histopathological diagnosis Diffuse Large B cell Lymphoma predominated (38 cases, 56.7\%) followed by Follicular lymphoma (17 cases, $25.4 \%$ ). IHC staining for LMP1 was done and $10.4 \%$ of cases showed LMP 1 positivity while $89.6 \%$ were negative. Among the $10.4 \%$ of LMP 1 positive NHL cases $3 \%$ showed weak positivity, $6 \%$ is moderate positivity and $1.5 \%$ showed intense positivity.

\begin{tabular}{|c|c|c|c|c|c|}
\hline \multicolumn{4}{|c|}{ Percentage of LMP-1 Positive Tumour Cells } & Frequency & (\%) \\
\hline \multicolumn{4}{|c|}{ None } & 60 & 89.6 \\
\hline \multicolumn{4}{|c|}{$1 \%-25 \%$} & 7 & 10.4 \\
\hline \multicolumn{4}{|c|}{$26 \%-50 \%$} & 0 & 0 \\
\hline \multicolumn{4}{|c|}{$51-75 \%$} & 0 & 0 \\
\hline \multicolumn{4}{|c|}{$76 \%-100 \%$} & 0 & 0 \\
\hline \multicolumn{4}{|c|}{ Total } & 67 & 100.0 \\
\hline \multicolumn{6}{|c|}{$\begin{array}{l}\text { Table 3. Distribution of Lymphomas According to } \\
\text { Percentage of Tumour Cells Positive for LMP-1 }\end{array}$} \\
\hline \multirow{5}{*}{ Cell Type } & & & \multicolumn{3}{|c|}{ LMP-1 } \\
\hline & & $\begin{array}{c}\text { Count } \\
\% \text { within cell type }\end{array}$ & $\begin{array}{c}6 \\
10.3 \%\end{array}$ & $\begin{array}{c}52 \\
89.7 \%\end{array}$ & $\begin{array}{c}58 \\
100.0 \%\end{array}$ \\
\hline & \multirow[t]{2}{*}{ T cell } & Count & 1 & 8 & 9 \\
\hline & & $\%$ within cell type & $11.1 \%$ & $88.9 \%$ & $100.0 \%$ \\
\hline & Total & $\begin{array}{l}\text { Count } \\
\% \text { within cell type }\end{array}$ & $\begin{array}{c}7 \\
10.4 \%\end{array}$ & $\begin{array}{c}60 \\
89.6 \%\end{array}$ & $\begin{array}{c}67 \\
100.0 \%\end{array}$ \\
\hline \multicolumn{6}{|c|}{ Table 4. Association between Cell Type and LMP-1 Positivity } \\
\hline \multicolumn{6}{|c|}{$\begin{array}{l}\mathrm{p} \text { value was }>0.05 \text { so there was no significant association between LMP } 1 \text { positivity } \\
\text { and B cell or T cell lymphoma. }\end{array}$} \\
\hline
\end{tabular}

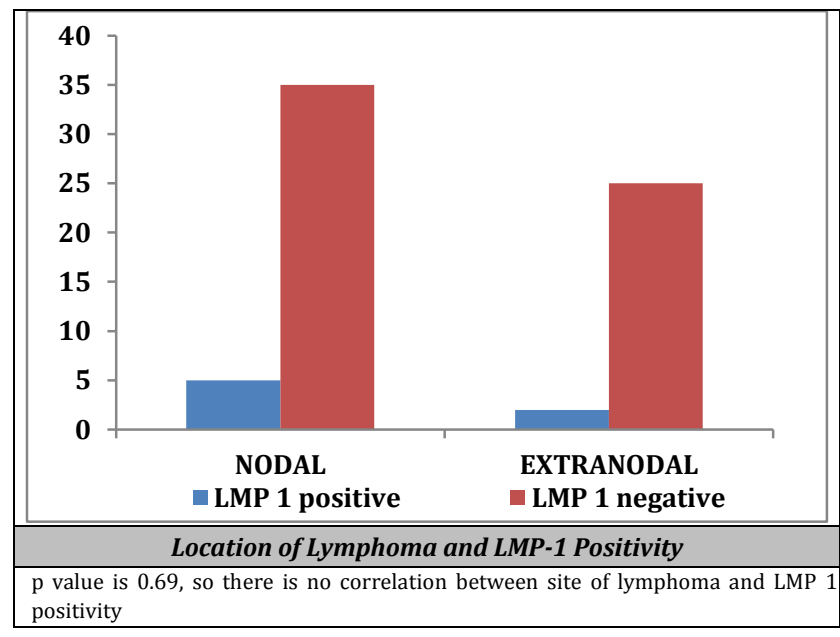

\begin{tabular}{|cccc|}
\hline Histopathology & LMP1 Positive & LMP 1 Negative & Total \\
DLBCL & 4 & 34 & 38 \\
Follicular Lymphoma & 1 & 16 & 17 \\
Peripheral T cell lymphoma, NOS & 0 & 4 & 4 \\
Anaplastic large cell lymphoma & 1 & 1 & 2 \\
SLL/CLL & 1 & 1 & 2 \\
T cell rich B cell lymphoma & 0 & 1 & 1 \\
Cutaneous T cell lymphoma & 0 & 3 & 3 \\
Total & $\mathbf{7}$ & $\mathbf{6 0}$ & $\mathbf{6 7}$ \\
\hline Histopathology Subtypes and LMP-1 Positivity \\
\hline
\end{tabular}

\section{DISCUSSION}

Role of EBV role in tumorigenesis of Non-Hodgkin's lymphoma is becoming more obvious, while still the management remains unsatisfactory. Exploration of antiviral drugs and therapies based on specific monoclonal antibodies has encouraging results. ${ }^{6}$ 
Immunohistochemistry has been developed as an efficient tool to demonstrate the presence of EBV by detecting latent viral antigens. LMP-1 is a viral oncogene which codes for an integral membrane protein and is essential for transformation of $\mathrm{B}$ cells by EBV. LMP-1 enhances the proliferation of host cells and also helps in blocking of their apoptosis. LMP-1 expression is membranous and cytoplasmic.

The present study was conducted in 67 cases of NonHodgkin's lymphoma received in Department of Pathology, Government medical college, Kottayam during December 2017 to May 2019. Immunostaining for LMP-1 was done in all cases and it is interpreted.

Our study had $10.4 \%$ ( 7 out of 67 cases) of LMP 1 positive NHLs which is comparable with the study of Sheeba Ishtiaq et al and Ashraf MJ et al.7,8 But Amal Ismail et al had 17\% of NHL with LMP-1 positivity. This may be because their study comprised mostly of Burkitt lymphoma. On the other hand there was no Burkitt lymphoma in our study.

NHL was seen in both lymph nodes $(60 \%)$ and extranodal $(40 \%)$. Cervical lymph nodes were the most common to be involved followed by supraclavicular and axillary nodes. Among the extranodal sites oropharyngeal lymphomas predominated $(10.4 \%)$. Among the 67 cases studied there were 58 cases of B cell lymphomas and 9 cases of and $\mathrm{T}$ cell lymphomas. Among the LMP 1 positive NHL, 28.5\% (2 out of 7) showed weak positivity, $57.1 \%$ (4 out of 7) showed moderate positivity and $14.28 \%$ ( 1 out of 7 ) cases showed intense positivity. 6 out of 58 cases of B cell lymphoma were positive for LMP 1 whereas only 1 out of 9 case of T cell lymphoma was positive. There was no significant association between LMP 1 positivity and cell type (i.e. B cell and T cell) with a $\mathrm{p}$ value of 1.0 .

\section{CONCLUSIONS}

LMP 1 was positive in $10.4 \%$ of cases of Non-Hodgkin's Lymphoma. There was no significant association between LMP 1 expression in $\mathrm{B}$ cell and $\mathrm{T}$ cell lymphoma with a $\mathrm{p}$ value of 1.0. This suggests that EBV might play a role in the pathogenesis of Non-Hodgkin's Lymphoma.
Limitations

The sample size was comparatively low. The heterogeneous staining of immunohistochemical antibodies can lead to subjective variations and errors. This study was done on limited number of cases with limited diagnostic tools such as IHC. Inclusion of more samples with further molecular diagnostic techniques like PCR and ERB 1 in situ hybridisation can yield a better result.

\section{REFERENCES}

[1] Swerdlow SH, Campo E, Harris NL, et al. WHO classification of tumours of haematopoietic and lymphoid tissues. Revised $4^{\text {th }}$ edn. IARC Lyon 2017.

[2] International Agency for Research on Cancer, World Health Organisation. Cancer Today, 2019.

[3] Ismail A, Osman I, Husain NE. LMP1 immunohistochemistry in Non-Hodgkin's Lymphoma of Sudanese cases. Open Journal of Pathology 2016;6(2):79-87.

[4] Grywalska E, Rolinski J. Epstein-Barr virus-associated lymphomas. Semin Oncol 2015;42(2):291-303.

[5] Tse E, Kwong YL. Epstein Barr Virus-associated lymphoproliferative diseases: the virus as the therapeutic agent. Experimental \& Molecular Medicine 2015;47(1):e136.

[6] Nourse JP, Crooks P, Keane C, et al. Expression profiling of Epstein-Barr Virus-encoded microRNAs from paraffinembedded formalin-fixed primary Epstein-Barr Viruspositive B-Cell lymphoma samples. Journal of Virological Methods 2012;184(1-2):46-54.

[7] Ishtiaq S, Hassan U, Mushtaq S, et al. Determination of frequency of Epstein-Barr Virus in Non-Hodgkin lymphomas using EBV latent membrane Protein 1 (EBVLMP1) immunohistochemical staining. Asian Pacific J Cancer Prev 2013;14(6):3963-7.

[8] Ashraf MJ, Makarempour A, Monabati A, et al. Comparison between presence of Epstein Barr Virus in nodal and extra nodal diffuse large B Cell lymphoma of head and neck, an Iranian experience. Iran Red Cres Med J 2012;14(12):764-70. 